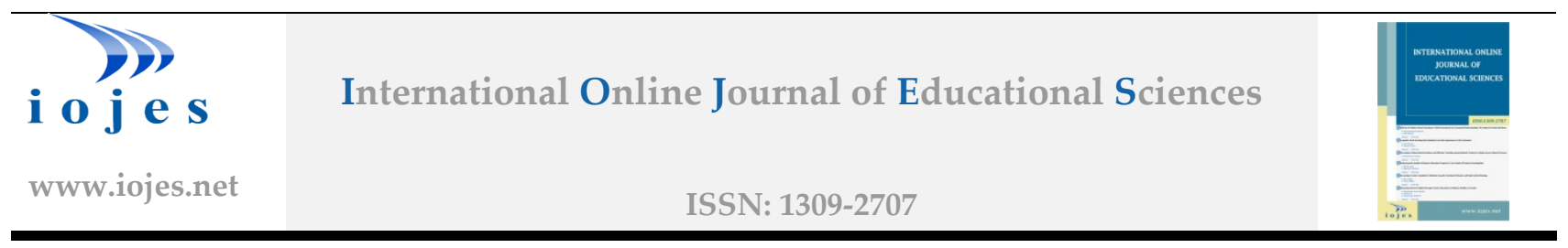

\title{
The Relationship between Social Emotional Learning Competencies and Life Satisfaction in Adolescents: Mediating Role of Academic Resilience
}

\section{Research Article}

\section{Mehmet Emin TURAN ${ }^{1}$}

${ }^{1}$ Agri Ibrahim Cecen University, Faculty of Education, Department of Psychological Counseling and Guidance, Agri, Turkey, ORCID: 0000-00018092-9642

To cite this article: Turan, M. E. (2021). The relationship between social emotional learning competencies and life satisfaction in adolescents: Mediating role of academic resilience, International Online Journal of Educational Sciences, 13(4), 1126-1142.

\begin{tabular}{ll} 
ARTICLE INFO & ABSTRACT \\
\hline Article History: & $\begin{array}{l}\text { Social-emotional learning (SEL) competencies has been the subject of many studies. The purpose of } \\
\text { this study was to examine the mediating role of academic resilience in the relationship between } \\
\text { adolescents' social-emotional learning competencies and life satisfaction. The study group was } \\
\text { Received: 04.02.2021 }\end{array}$ \\
composed of 371 adolescents. Self-report measurement tools were used in the study. Structural \\
equation modeling was used to investigate the mediating role of academic resilience in the \\
relationship between social-emotional learning and life satisfaction. As a result of the study, it was \\
concluded that social-emotional learning competencies predicted life satisfaction and academic \\
resilience. Also, academic resilience predicted life satisfaction. As a result of this study, it has been \\
concluded that academic resilience has a mediating effect on the relationship between social- \\
emotional learning competencies and life satisfaction. It is suggested that include academic resilience \\
activities in SEL programs to be developed to increase the quality of life, happiness, well-being and \\
life satisfaction.
\end{tabular}

(C) 2021 IOJES. All rights reserved

Keywords:

Social-emotional learning competencies, life satisfaction, academic resilience, mediation, adolescence

\section{Introduction}

Adolescence has been considered as one of the life periods in which most developmental difficulties are experienced individually. Adolescents may experience problems in many different areas (social, emotional, psychological, and vocational). Adolescence is considered as an important and sensitive period in emotional development (Woodard \& Pollak, 2020) to be a period of life spanning 10 to 19 years of age (WHO, 2006). The management and regulation of emotions are seen so important in maintaining adaptive psychosocial functionality in adolescence period. Individuals obtain valuable information about their environment,

${ }^{1}$ Corresponding author's address: Agri Ibrahim Cecen University

Telephone: +905339651092

e-mail: meturan@agri.edu.tr

DOI: https://doi.org/10.15345/iojes.2021.04.012 
themselves, and their relationships with the environment through emotions (Zeman et al., 2006). It is stated that there are relationships between adolescents' emotions and stress levels, risky behaviors, even psychopathology (Gilbert, 2012). In this context, it can be thought that emotional experiences can contribute to the well-being of adolescents.

Emotional intelligence is the basis of social-emotional learning competencies (Antoñanzas et al., 2014) and it is defined as "the ability to monitor one's own and others' feelings and emotions, to discriminate among them and to use this information to guide one's thinking and actions" (Salovey \& Mayer, 1990, p.189). Emotional intelligence and emotions (such as the long-term effects of expressing emotions) have been determined to predict the positive social behavior and academic competence of children at risk (Izard et al., 2001). Besides, it has been concluded that emotional intelligence (emotional abilities) predicts social and academic adaptation to school in adolescents (Mestre et al., 2006).

Emotional intelligence also can contribute to healthy personal development and increasing life satisfaction (Salovey \& Mayer, 1990). For instance, adolescents' emotional intelligence can be considered as a protective factor that reduces negative symptoms related to problematic internet and smartphone use (Arrivillaga et al., 2020). Social-emotional learning competencies, which is based on emotional intelligence, is becoming increasingly widespread. Interventions and teaching activities based on social-emotional learning are carried out around multiple cultures.

\section{Social-Emotional Learning}

The relationship between emotional intelligence and education is getting more evidence-based day by day. Emotional intelligence plays an important role in the education and training process. Education practices related to emotional intelligence are now considered in a social-emotional context (Antoñanzas et al., 2014). Social-emotional learning competencies means that individuals acquire knowledge and skills that will enable them to better manage their emotions and empathize. Social-emotional learning competencies is associated with coping strategies, critical thinking, and responsible decision making (Cahill \& Dadvand, 2020; Frydenberg, 2010).

Social-emotional learning competencies is generally addressed in three interrelated skill sets. Cognitive processes, emotional processes, and interpersonal skills are skill sets categorized under Social-emotional learning competencies (Jones \& Bouffard, 2012). Cognitive processes refer to students' positive attitudes to learning and learning abilities, functional and attention skills. Emotional processes include regulation of emotion and empathy. Interpersonal skills include the ability to develop peer and teacher relationships depending on students to become aware of social cues and having positive social interactions (Jones \& Bouffard, 2012). The Collaborative on Social-Emotional Learning (CASEL) organization defines five socialemotional core competencies; 1-self-awareness, 2-self-management, 3-responsible decision-making, 4relationship skills, and 5-social awareness (Weissberg et al., 2015). Researchers also have different views about social-emotional learning competencies. For instance, Corcoran \& Tormey (2013) stated that social-emotional competence comprises two areas as ability and performance.

\section{Life Satisfaction}

The pursuit of happiness has been a subject of interest to people of all ages (Proctor et al., 2009). Happiness has been considered as the most basic indicator of the good life that people want to achieve. In the field of psychology, the concept of happiness is considered a subjective well-being concept (Diener et al., 2003). Life satisfaction is considered as an "important positive indicator" of individual's subjective well-being (Liu et al., 2013). 
Life satisfaction can be conceptualized as a cognitive evaluation of the individual's satisfaction overall with his life (Diener et al., 2003; Lucas et al., 1996; Turan \& İskender, 2020). Life satisfaction has been the subject of many studies because it is closely related to well-being and psychopathology (Proctor et al., 2009; Savci et al., 2020). The main purpose of many psychological interventions is to increase life satisfaction (Chang et al., 2003; Kwok et al., 2016).

\section{Academic Resilience}

The concept of resilience has subjective, cognitive, and physiological properties. Resilience is explained by the metaphor of cast iron and wrought iron. The fact that wrought iron is flexible and more difficult to break (resilient) compared to cast iron (brittle). This metaphor is similar to the process of individuals with resilience to bounce back in the face of adversity and traumas (Tugade \& Fredrickson, 2004). Resilience is a multidimensional concept defined as the ability to adapt positively to negative life events (Gartland et al., 2011). Resilience also has been expressed as the "process of adapting well to trauma, tragedy, and threats" and "resilience involves bouncing back from difficult experiences, and it can involve profound personal growth" by American Psychological Association (APA, 2020, para. 4). Resilience is related to effective functioning in life (Klohnen, 1996), finding positive meaning in negative circumstances (Tugade \& Fredrickson, 2004), mental health (Davydov et al., 2010), and self-esteem (Benetti \& Kambouropoulos, 2006).

Academic resilience is a concept that expresses the level of individuals' ability to overcome academic stress. It was stated that the affective factor of academic resilience predominated (Mwangi et al., 2015). Academic resilience refers to the coping level of an individual who experiences negative academic events. Academic resilience is a psychological construct that contributes to individuals' academic success. It is known that academic achievement and school performance of resilient students do not decrease even during stressful situations (Martin \& Marsh, 2006).

\section{Academic Resilience as a Mediator in Relationship between Social-Emotional Learning Competencies and Life Satisfaction}

Social-emotional development can foster life satisfaction. For instance, it was found that positive socialemotional relationships and social support affect life satisfaction in adolescents positively (Proctor et al., 2009). This situation indicates that social-emotional learning competencies can increase life satisfaction. Socialemotional learning competencies also is effective in increasing well-being. Social-emotional learning competencies can reduce the depression, distress, and anxiety levels of students (Durlak et al. 2011; Stockings et al. 2016; Wang et al. 2016). Social-emotional learning competencies is related to reducing risk-taking behaviors and improving well-being (Cahill \& Dadvand, 2020).

Resilience can enable positive emotions to be used effectively. Positive emotions and emotion regulation can be considered as important factors associated with resilience (Tugade \& Fredrickson, 2004). Socialemotional learning competencies can increase resilience (Hromek \& Roffey 2009). Schools are important institutions for the positive development of students. Positive experiences at school (psychological, social, and emotional) can help students develop positive feelings towards school and reduce academic stress (Abolghasemi \& Varaniyab, 2010). In this direction, it can be thought that social-emotional-based learning activities carried out in schools and social-emotional learning competencies can increase the academic resilience of students.

Resilience also can increase life satisfaction (Cohn et al., 2009). Abolghasemi \& Varaniyab (2010) found that resilience predicted life satisfaction in the students of success and failure. Haddadi \& Besharat (2010) found that resilience is related to psychological well-being. As a result, it can be said that resilience can have a positive effect on life satisfaction. Grades also predict life satisfaction in children (Chang et al., 2003). In this direction, it can be thought that academic resilience can increase life satisfaction. 
There are many studies show that personality traits are predictors of life satisfaction (Diener et al., 2003; Steel et al., 2008). Emotional intelligence, which forms the theoretical basis of social-emotional learning competencies (Antoñanzas et al., 2014), and academic resilience (Tamannaeifar \& Shahmirzaei, 2019) is considered as concepts closely related to personality traits. Accordingly, it can be expected that socialemotional learning competencies and academic resilience predict life satisfaction. Cohn et al. (2009) found that resilience plays a mediating role in the relationship between positive emotions and life satisfaction. Besides, Tugade \& Fredrickson (2004) reported that positive emotions are related to positive meaning in difficult life conditions of high resilient individuals. All these findings point out the mediating role of academic resilience in the relationship between social-emotional learning competencies and life satisfaction.

Academic resilience has been considered as a mediating variable in many conceptual relationships. For instance, Choo \& Prihadi (2019) found that academic resilience plays a mediating role in the relationship between multidimensional perfectionism and academic performance. Secer \& Ulas (2020) found that academic resilience has a mediating role in the relationship between anxiety sensitivity, social and adaptive functioning, school refusal, and school attachment. Social-emotional learning competencies is closely related to life satisfaction, resilience, and academic success (Cahill \& Dadvand, 2020). When the relationship of socialemotional learning with both academic success (Durlak et al. 2011) and resilience (Smith, 2012) is generally evaluated, it is thought that academic resilience may have a mediating role in the relationship between socialemotional learning competencies and life satisfaction.

Therefore, I proposed the following hypotheses (see figure 1):

Hypothesis 1: Social-emotional learning competencies is related to life satisfaction.

Hypothesis 2: Social-emotional learning competencies is related to academic resilience.

Hypothesis 3: Academic resilience is related to life satisfaction.

Hypothesis 4: Academic resilience has a mediating effect on the relationship between social-emotional learning competencies and life satisfaction.

\section{Method}

\section{Participants}

393 high school students participated in the study. The data of 10 students who filled the scales incompletely were not included in the study. 12 multivariate outliers data $(p<.001)$ that did not meet the normality and linearity assumptions were also not included in the study. The last study group consists of 371 high school students. The ages of the study participants ranged from 14 to 19 . The average age of the participants in the study is 16.04. Permission was obtained from the ethics committee of the author's university for the study. The study was conducted at all by using the Declaration of Helsinki ethical guidelines. All students participating in the study participated in the study voluntarily. The time for completing the scales for the participants of the study took between 10 and 30 minutes. The study included 6 individuals at the age of 14,118 individuals at the age of 15,129 individuals at the age of 16,96 individuals at the age of 17,18 individuals at the age of 18, and 4 individuals at the age of 19. Findings regarding other demographic characteristics of the study group are presented in Table 1. 
Table 1. Sample characteristics

\begin{tabular}{lcc}
\hline Variable & Frequency $(\boldsymbol{n})$ & $\%$ \\
\hline Gender & 192 & 51.8 \\
Female & 179 & 48.2 \\
Male & & 38.3 \\
\hline Grade & 142 & 32.6 \\
9 & 121 & 23.2 \\
10 & 86 & 5.9 \\
11 & 22 & 54.4 \\
12 & & 45.6 \\
\hline Financial status & 202 & \\
National minimum wage and below & 169 & 35.8 \\
National minimum wage above & & 53.1 \\
\hline Grade (out of 100) & 133 & 11.1 \\
70 and above & 197 & 41 \\
50 between 70 & 49 & \\
50 and below & & \\
\hline
\end{tabular}

\section{Measurement Tools}

Adolescents' Social and Emotional Learning Scale. Adolescents' Social and Emotional Learning Scale was developed by Totan (2018). The scale consists of 23 items. It is a 5-point Likert-type scale. High scores from the scale indicate that social and emotional learning competencies is high levels. The minimum score that can be obtained from the scale is 23 and the maximum score is 115 . The internal consistency reliability coefficient of the scale was found to be .88 in this study.

Satisfaction with Life Scale. The scale was developed by Diener et al. (1985). The adaptation study of the scale was conducted by Köker (1991). The scale consists of 5 items. It is a 7-point Likert-type scale. High scores from the scale indicate a high level of life satisfaction. The minimum score that can be obtained from the scale is 5 and the maximum score is 35 . In this study, the internal consistency reliability coefficient of the scale was found to be 85 .

Academic Resilience Scale. The Academic Resilience Scale was developed by Martin \& Marsh (2006). The adaptation study of the scale was conducted by Kapıkıran (2012). The scale consists of 6 items. It is a 6point Likert-type scale. High scores on the scale indicate a high level of academic resilience. The minimum score that can be obtained from the scale is 6 and the maximum score is 42 . In this study, the internal consistency reliability coefficient of the scale was found to be .81 .

\section{Data analysis}

Confirmatory factor analysis (CFA) and structural equation modeling (SEM) were implemented using SPSS Amos v21 software. Since the data provides normal distribution, the maximum likelihood method was used. In the measurement model, it was determined that there were a total of 21 parameters, 9 regression, 3 covariances, and 9 variances in the study, in line with 10 participant rules for each parameter. In line with the rule that the number of participants should be 10 for each parameter, it was calculated that the sufficient number of participants for the study was 210. In this direction, it was determined that the number of participants required for each parameter in this study was higher than 10 (371 participants). To test the hypotheses of this study, SEM was applied by the item parcelling method (Bandalos, 2002). It was found that the coefficients of skewness and kurtosis ranged between -1.5 and +1.5 (Tabachnick \& Fidell, 2013). The binary correlation coefficients were found to be less than .85. It was also found that VIF values are less than 10 . These 
results show that there is no multicollinearity problem. The values of fit goodness of the model were calculated with chi-square /degrees of freedom, RMSEA, SRMR, GFI, NFI, CFI, and IFI values.

\section{Results}

Descriptive statistics and binary correlations of the variables of the study are presented in Table 2 . Findings indicated that social-emotional learning competencies is positively associated with life satisfaction (ranging $r=.14$ to .30 ) and academic resilience (ranging $r=.20$ to .30 ). It was also found that life satisfaction and academic resilience (ranging $r=.28$ to .33 ) have a positive relationship. It was concluded that all the variables of the study are correlated. 
Table 2. Descriptive Statistics and Binary Correlations among Study Variables

\begin{tabular}{|c|c|c|c|c|c|c|c|c|c|c|c|c|c|}
\hline \multirow[b]{2}{*}{ Variable } & \multicolumn{4}{|c|}{ Descriptive Statistics } & \multicolumn{9}{|c|}{ Correlations } \\
\hline & $\mathbf{M}$ & SD & Skewness & Kurtosis & 1 & 2 & 3 & 4 & 5 & 6 & 7 & 8 & 9 \\
\hline 1.SEL-Par1 & 13,80 & 3,49 & -.32 & -.22 & - & $.44^{* *}$ & $.52^{* *}$ & $.49^{* *}$ & $.47^{* *}$ & $.30^{* *}$ & $.22^{* *}$ & $.28^{* *}$ & $27^{* *}$ \\
\hline 2.SEL-Par2 & 14,62 & 3,36 & -.40 & .02 & & - & $.62^{* *}$ & $.57^{* *}$ & $.47^{* *}$ & $.14^{* *}$ & $.15^{* *}$ & $.26^{* *}$ & $26^{* *}$ \\
\hline 3.SEL-Par3 & 18,46 & 3,87 & -.50 & .45 & & & - & $.65^{* *}$ & $.57^{* *}$ & $.24^{* *}$ & $.25^{* *}$ & $.26^{* *}$ & $30^{* *}$ \\
\hline 4.SEL-Par4 & 18,47 & 3,78 & -.51 & .29 & & & & - & $.60^{* *}$ & $.18^{* *}$ & $.17^{* *}$ & $.23^{* *}$ & $20^{* *}$ \\
\hline 5.SEL-Par5 & 17,38 & 3,97 & -.48 & .60 & & & & & - & $.19^{* *}$ & $.20^{* *}$ & $.27^{* *}$ & $30^{* *}$ \\
\hline 6.LS-Par1 & 7,98 & 3,77 & -.11 & -1.13 & & & & & & - & $.76^{* *}$ & $.33^{* *}$ & $29^{* *}$ \\
\hline 7.LS-Par2 & 10,86 & 5,10 & .27 & .70 & & & & & & & - & $.28^{* *}$ & $31^{* *}$ \\
\hline 8.AR-Par1 & 14,03 & 4,32 & -.29 & -.33 & & & & & & & & - & $67^{* *}$ \\
\hline 9.AR-Par2 & 13,34 & 4,91 & -.34 & -.61 & & & & & & & & & - \\
\hline
\end{tabular}

Note. SEL-Par = parcels of social and emotional learning; LS-Par = parcels of life satisfaction; AR-Par = parcels of academic resilience. ${ }^{* *} p<.01$ 


\section{Measurement Model}

The measurement model of this study, which includes social emotional learning competencies, satisfaction with life and academic resilience variables, was found to fit the data well. Confirmatory factor analysis results $(\chi 2 / d f=1.83, p<$ $.001, \mathrm{RMSEA}=.047, \mathrm{SRMR}=.033, \mathrm{GFI}=.96, \mathrm{NFI}=.97, \mathrm{CFI}=0.99$, and IFI $=0.99$ ) provided evidence of good fit. Standardized and unstandardized coefficients for CFA are presented in Table 3.

Table 3. Standardized and Unstandardized Coefficients for CFA

\begin{tabular}{lllll}
\hline Observed variable & Latent construct & $\beta$ & B & SE \\
\hline SEL-Parcel1 & SEL & 0.64 & 1.00 & \\
SEL-Parcel2 & & 0.72 & 1.08 & 0.10 \\
SEL-Parcel3 & & 0.83 & 1.43 & 0.11 \\
SEL-Parcel4 & & 0.79 & 1.33 & 0.11 \\
SEL-Parcel5 & LS & 0.71 & 1.27 & 0.11 \\
LS- Parcel1 & & 0.89 & 1.00 & \\
LS- Parcel2 & AR & 0.85 & 1.29 & 0.13 \\
AR- Parcel1 & & 0.82 & 1.00 & \\
AR- Parcel2 & & 0.81 & 1.13 & 0.12 \\
\hline
\end{tabular}

Note. SEL = social and emotional learning, LS = life satisfaction, AR = academic resilience. SEL-Par = parcels of social and emotional learning; LS-Par = parcels of life satisfaction; AR-Par = parcels of academic resilience.

For convergent validity and reliability, also average variance explained value and composite reliability values were examined. The accepted composite reliability value is above .70 (Carmines \& Zeller,1988), and the average variance explained value is above .50 (Fornell \& Larcker 1981). In the present study, composite reliability varied from .80 to .87 . Average variance explained value varied from .55 to .76 . These results indicated convergent validity and good reliability.

\section{Structural Model}

Path analysis with structural equation modeling was carried out to analyze whether the hypotheses were supported. To examine the hypotheses of the study, two models were proposed in line with the structural equation modeling. In the first model, the predictive status of social emotional learning competencies on life satisfaction (hypothesis 1) was examined. In the second model, the predictive status of social-emotional learning competencies on academic resilience (hypothesis 2) and predictive status of academic resilience on life satisfaction (hypothesis 3) was examined. Besides, the mediating role of academic resilience in the relationship between social-emotional learning competencies and life satisfaction (hypothesis 4) was also examined. Model 1 and Model 2 are shown in Figure 1.

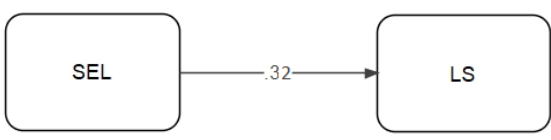

Model 1 - SEL ---> LS

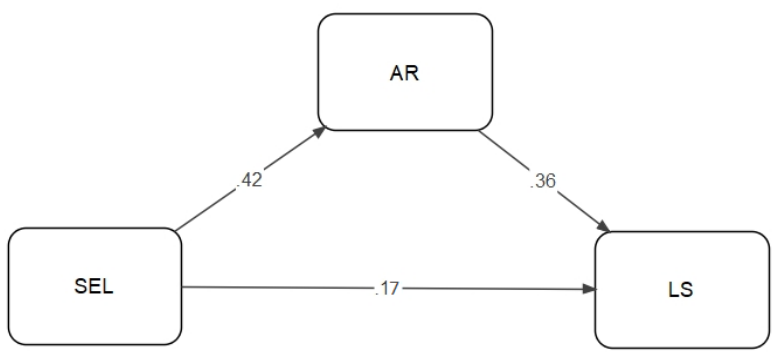

Model 2 - Mediational mode

Figure 1. Models of the study

Note. $\mathrm{SEL}=$ social and emotional learning, $\mathrm{LS}=$ life satisfaction, $\mathrm{AR}=$ academic resilience 
The results demonstrated that the model 1 provided a good fit to the data: $\chi 2 / d f=2.12, p<.001$, RMSEA $=.055, \mathrm{SRMR}=.034, \mathrm{GFI}=.98, \mathrm{NFI}=.98, \mathrm{CFI}=0.99$, and $\mathrm{IFI}=.99$. Also, results indicated that social emotional learning competencies had statistically significant positive effects on life satisfaction $(\beta=.32, t=4.89, p<.001)$, supporting hypothesis 1 . Likewise, model 2 provided a good fit to the data: $\chi 2 / d f=1.85, p<.001, \mathrm{RMSEA}=$ $.048, \mathrm{SRMR}=.034, \mathrm{GFI}=.97, \mathrm{NFI}=.97, \mathrm{CFI}=.99$, and $\mathrm{IFI}=.99$. The social emotional learning competencies had statistically significant positive effects on academic resilience $(\beta=.42, t=6.33, p<.001)$, supporting hypothesis 2 . In addition, academic resilience was found to have statistically significant positive effects on life satisfaction $(\beta=.36, t=4.98, p<.01)$, supporting hypothesis 3 . CFA results of models are presented in Table 4 . Positive effects of social emotional learning competencies on life satisfaction had decreased $(\beta=.17, t=2.42, p$ $<.01)$ in model 2.

Table 4. Summary of Fit Indicies for Models Tested

\begin{tabular}{llllllll}
\hline Model & $\chi \mathbf{2} / \mathbf{d f}$ & GFI & RMSEA & SRMR & NFI & CFI & IFI \\
\hline Model 1 - SEL $\rightarrow$ LS & 2.12 & .98 & .055 & .034 & .98 & .99 & .99 \\
Model 2- Mediational model & 1.85 & .97 & .048 & .034 & .97 & .99 & .99 \\
\hline
\end{tabular}

Note. SEL = social and emotional learning, LS = life satisfaction. GFI = Goodness-of-fit index; RMSEA = root mean square error of approximation; $\mathrm{SRMR}=$ standardized root mean square residual; NFI = normed fit index; $\mathrm{CFI}=$ comparative fit index; $\mathrm{IFI}=$ incremental fit index.

\section{Mediating Effect of Academic Resilience}

The two models (Model 1 and Model 2) were checked against the test of the mediating role of academic resilience in the relationship between social-emotional learning competencies and life satisfaction. Baron \& Kenny (1986) indicated that if the power of the relationship between a dependent variable and an independent variable is significantly statistically reduced after the inclusion of the mediation variable, the result demonstrates partial mediation. As a result, it can be said that academic resilience partially mediated the association between social-emotional learning competencies and life satisfaction.

\section{Bootstrapping}

Besides, the significance of the mediating role of academic resilience in the relationship between socialemotional learning competencies and life satisfaction was tested through the bootstrapping procedure. Table 5 shows direct and indirect effects with 95\% confidence interval. It is seen that the indirect effect of socialemotional learning competencies on life satisfaction through academic resilience is significant (bootstrap estimate $=.15,95 \%$ CI $[.089, .237])$.

Table 5. Direct, Indirect Effects, and $95 \%$ Confidence Intervals for the Mediational Model

\begin{tabular}{llll}
\hline Model Pathways & Estimated & $\begin{array}{l}\text { 95\% CI } \\
\text { Lower }\end{array}$ & Upper \\
\hline Direct Effect & & & \\
SEL $\rightarrow$ LS & .17 & .044 & .316 \\
SEL $\rightarrow$ AR & .42 & .265 & .552 \\
AR $\rightarrow$ LS & .36 & .232 & .501 \\
Indirect Effect & & & \\
SEL $\rightarrow$ AR $\rightarrow$ LS & .15 & .089 & .237
\end{tabular}

Note. $\mathrm{SEL}=$ social and emotional learning, $\mathrm{LS}=$ life satisfaction, $\mathrm{AR}=$ academic resilience.

\section{Discussion}

Emotional intelligence theorized by Salovey \& Mayer (1990) states that recognizing, understanding, using, and managing emotions in different areas in life manifests itself and contributes to the life adaptation 
of the individuals. Social-emotional learning competencies can be considered within the scope of emotional intelligence. Therefore, emotional intelligence theorized by Salovey \& Mayer (1990) is closely related to wellbeing.

The prediction of social-emotional learning competencies on life satisfaction expressed in Hypothesis 1 is one of the results of this study (see model 1). The idea that social-emotional learning competencies will increase the well-being of adolescents is also supported by the data of this study. Social-emotional learning competencies for adolescents also are considered as a strategy that supports adolescents' well-being. Socialemotional learning competencies can enable adolescents to develop skills that increase well-being and support positive relationships (Elbertson et al. 2010). This finding is consistent with the assumption that socialemotional learning competencies is related with the life satisfaction.

Previous studies have found a relationship between a decrease in substance use and an increase in life satisfaction. Social-emotional learning competencies is also effective in reducing substance abuse (Midford et al. 2014; 2018) and suicidal ideation (Gravesteijn et al. 2011). The fact that social-emotional learning competencies reduces substance abuse is consistent with the finding that social-emotional learning competencies has an effect on life satisfaction obtained as a result of this study. In this context, it can be argued that the development of social-emotional learning competencies can be effective in both increasing life satisfaction, promoting the quality of life, and combating substance addiction.

Life satisfaction is seen as the "key indicator" of subjective well-being. The concepts of well-being and happiness have been used as synonyms in some studies (Proctor et al., 2009). The concept of well-being and happiness were used as synonyms in some studies (Proctor et al., 2009). In terms of positive psychology, happiness is seen as the main goal to be reached. It has been stated that happy individuals are healthier and more successful when compared to unhappy individuals (Seligman et al., 2005). Emotional intelligence has been evaluated as a multidimensional concept consisting of "perceiving emotions", "using emotions", "understanding emotions" and "managing emotions" (Salovey et al., 2008; p.188), and social-emotional learning competencies is based on emotional intelligence (Cohen, 1999; Salovey et al., 2008). Ciarrochi et al. (2000) found that there are relationships between emotional intelligence and life satisfaction in line with the findings of this study.

Social-emotional learning competencies' prediction of life satisfaction may be related to empathy. The relationship of emotional intelligence and empathy has been demonstrated in many studies (Castillo et al., 2013; Fernández-Abascal \& Martín-Díaz, 2019). Studies show that empathy is related to life satisfaction (Guasp Coll et al., 2020; Marilaf Caro et al., 2017). When the relationships between emotional intelligence, empathy, and life satisfaction are examined, it can be thought that there is a connection between empathy and the mechanism in the predictive relationship between social-emotional learning competencies and life satisfaction.

The second hypothesis of this study is that social-emotional learning competencies is related to academic resilience. As a result of this study, it was concluded that social-emotional learning competencies predicted academic resilience. This finding is consistent with previous researches. In the studies, it was concluded that social-emotional learning competencies is related to academic achievement (Corcoran et al, 2018) and academic resilience (Wills \& Hofmeyr, 2019).

In addition, social-emotional learning competencies was found to be effective in dealing with bullying. SEL is one of the strategies used in bullying-related interventions in terms of content. It can increase the communication skills of adolescents that are effective in coping with bullying (Garrard \& Lipsey 2007; Wilson \& Lipsey 2007). Coping with bullying is a concept closely related to resilience (Ran, et al., 2020).

The third hypothesis that academic resilience is related to life satisfaction is also consistent with previous studies (Abolghasemi \& Varaniyab, 2010; Liu et al., 2012; Liu et al., 2013). The relationship between 
school success and life satisfaction has been shown in previous studies (Kim \& Jeong, 2017; Ng et al., 2015). Academic resilience is a concept associated with school success. It has been found that individuals with high academic resilience have higher school grades (Hwang \& Shin, 2018). Therefore, the relation of academic resilience and life satisfaction may be due to the relationships between academic achievement, resilience, and life satisfaction.

The fourth and final hypothesis of this study is that academic resilience has a mediating effect on the relationship between social-emotional learning competencies and life satisfaction, and this hypothesis was confirmed. Academic resilience is a special type of resilience (Martin \& Marsh, 2006). There are research findings on the mediating role of academic resilience (e.g. Choo \& Prihadi, 2019) and resilience (e.g. Tugade \& Fredrickson, 2004). The reason why academic resilience has a mediator role may be due to the relationship between school success and life satisfaction.

School success is a concept closely related to both emotional intelligence (Zandi, 2012) and resilience (Van Hoek et al., 2019). Therefore, the relationships between school success and life satisfaction, emotional intelligence may contribute to the mediating role of academic resilience. Besides, Ciarrochi et al. (2000) argued that IQ is an important factor in analyzing emotional processes. IQ is a concept that closely relates to academic success. Academic success can improve academic resilience. The relationship between IQ and emotional processes may contribute to the mediating role of academic resilience in the relationship between socialemotional learning competencies and life satisfaction.

Tugade \& Fredrickson (2004) also found that positive emotions have a mediating role in the relationship between resilience and finding positive meaning. The mediating role of academic resilience may be due to its relation to emotions and finding meaning in life. Finding meaning in life is a concept closely related to life satisfaction. On the other hand, emotions are considered as the main source of social-emotional learning competencies in many sources.

Schools are institutions on which the socialization process of children and young people is based, as well as academic teaching (Gillies, 2003). It is thought that this process has existed from the beginning of formal education and stated that schools play a role in teaching social, emotional, and ethical issues. For example, the phrase "Know Thyself" in Ancient Greece is a phrase associated with social-emotional learning (Cohen, 2006). Social-emotional learning competencies can be considered as one of the goals of education from past to present. The mediator role of academic resilience in the relationship between social-emotional learning competencies and life satisfaction indicates that more attention should be paid to the academic aspect of resilience.

It has been stated that conceptualizing and measuring social-emotional learning is complex in previous studies (Corcoran et al., 2020). In this direction, this study can be repeated with measurement tools with different theoretical backgrounds and different social-emotional learning competencies. In addition, the data of this study were collected using self-report measurement tools in parallel with many studies in the socialemotional learning literature. The data of this study can be repeated by measuring the performance evaluation of social-emotional learning. In addition, repeating the study data with qualitative methods such as observation and interview may contribute to the generalizability of the study data.

\section{Conclusion}

In this study, it is concluded that social-emotional learning competencies predict life satisfaction. In addition, the results that social-emotional learning competencies predict academic resilience and academic resilience predict life satisfaction, are also among the findings of the study. Mediation analysis is a technique used to determine the structures that indirectly contribute to causation in examining cause and effect mechanisms among variables. Mediation explains the causality between variables or structures (MacKinnon 
et al., 2007). Accordingly, it is concluded that academic resilience has a partial mediating effect on the relationship between social-emotional learning competencies and life satisfaction. SEL programs are increasingly common today. Interest in SEL programs is increasing day by day in many countries (Cahill \& Dadvand, 2020).

As a result of this study, it was concluded that the academic resilience component is so important in the effectiveness of -social-emotional learning competencies predicting life satisfaction-. Life satisfaction is considered as one of the components of quality of life and psychological well-being (Proctor et al., 2009). It is thought that giving more attention to academic resilience activities while planning social-emotional learning activities. In conclusion, this research has indicated evidence on the relationships between social-emotional learning competencies, academic resilience, and life satisfaction. 


\section{REFERENCES}

Abolghasemi, A., \& Varaniyab, S. T. (2010). Resilience and perceived stress: predictors of life satisfaction in the students of success and failure. Procedia - Social and Behavioral Sciences, 5, 748-752. doi: 10.1016/j.sbspro.2010.07.178

American Psychological Association. (2020, February 1). Building your resilence. Retrieved from http://www.apa.org/topics/resilience

Antoñanzas, J. L., Salavera, C., Teruel, P., Sisamon, C., Ginto, A. I., Anaya, A., \& Barcelona, D. (2014). Emotional intelligence and personality in student teachers. Procedia - Social and Behavioral Sciences, 132, 492-496. doi: 10.1016/j.sbspro.2014.04.342

Arrivillaga, C., Rey, L., \& Extremera, N. (2020). Adolescents' problematic internet and smartphone use is related to suicide ideation: Does emotional intelligence make a difference? Computers in Human Behavior, 110, 106375. doi: 10.1016/j.chb.2020.106375

Baron, R. M., \& Kenny, D. A. (1986). The moderator-mediator variable distinction in social psychological research. Journal of Personality and Social Psychology, 51(6), 1173-1182. doi: 10.1037/0022-3514.51.6.1173

Benetti, C., \& Kambouropoulos, N. (2006). Affect-regulated indirect effects of trait anxiety and trait resilience on self-esteem. Personality and Individual Differences, 41(2), 341-352. doi: 10.1016/j.paid.2006.01.015

Cahill H., Dadvand B. (2020). Social and emotional learning and resilience education. In R. Midford, G. Nutton, B. Hyndman \& S. Silburn (Eds.), Health and education interdependence (pp. 205-223). Singapore: Springer. doi: 10.1007/978-981-15-3959-6_11

Carmines, E.G., \& Zeller, R.A. (1988). Reliability and validity assessment. Newbury Park: Sage.

Castillo, R., Salguero, J. M., Fernández-Berrocal, P., \& Balluerka, N. (2013). Effects of an emotional intelligence intervention on aggression and empathy among adolescents. Journal of Adolescence, 36(5), 883-892. doi: 10.1016/j.adolescence.2013.07.001

Chang, L., Mcbride-Chang, C., Stewart, S. M., \& Au, E. (2003). Life satisfaction, self-concept, and family relations in Chinese adolescents and children. International Journal of Behavioral Development, 27(2), 182189. doi: $10.1080 / 01650250244000182$

Choo, O. Z. H., \& Prihadi, K. D. (2019). Academic resilience as mediator of multidimensional perfectionism and academic performance among gen- $Z$ undergraduate students. International Journal of Evaluation and Research in Education, 8(4), 637-646. doi: 10.11591/ijere.v8i4.20340

Ciarrochi, J. V., Chan, A. Y. C., \& Caputi, P. (2000). A critical evaluation of the emotional intelligence construct. Personality and Individual Differences, 28(3), 539-561. doi: 10.1016/s0191-8869(99)00119-1

Cohen, J. (1999). Social and emotional learning past and present: A psychoeducational dialogue. In J. Cohen (Ed.), Educating minds and hearts: Social emotional learning and the passage into adolescence (pp. 2-23). New York: Teachers College Press.

Cohen, J. (2006). Social, emotional, ethical, and academic education: Creating a climate for learning, participation in democracy, and well-being. Harvard Educational Review, 76(2), 201-237. doi: 10.17763/haer.76.2.j44854x1524644vn

Cohn, M. A., Fredrickson, B. L., Brown, S. L., Mikels, J. A., \& Conway, A. M. (2009). Happiness unpacked: Positive emotions increase life satisfaction by building resilience. Emotion, 9(3), 361-368. doi: $10.1037 / \mathrm{a} 0015952$

Corcoran, R. P., \& Tormey, R. (2013). Does emotional intelligence predict student teachers' performance? Teaching and Teacher Education, 35, 34-42. doi: 10.1016/j.tate.2013.04.008.

Corcoran, R. P., Cheung, A. C. K., Kim, E., \& Xie, C. (2018). Effective universal school-based social and emotional learning programs for improving academic achievement: A systematic review and metaanalysis of 50 years of research. Educational Research Review, 25, 56-72. doi: 10.1016/j.edurev.2017.12.001 
Corcoran, R. P., O'Flaherty, J., Xie, C., \& Cheung, A. C. K. (2020). Conceptualizing and measuring social and emotional learning: A systematic review and meta-analysis of moral reasoning and academic achievement, religiosity, political orientation, personality. Educational Research Review, 30, 100285. doi: 10.1016/j.edurev.2019.100285

Davydov, D. M., Stewart, R., Ritchie, K., \& Chaudieu, I. (2010). Resilience and mental health. Clinical Psychology Review, 30(5), 479-495. doi: 10.1016/j.cpr.2010.03.003

Diener, E., Emmons, R. A., Larsen, R. J., \& Griffin, S. (1985). The Satisfaction With Life Scale. Journal of Personality Assessment, 49(1), 71-75. doi: 10.1207/s15327752jpa4901_13

Diener, E., Oishi, S., \& Lucas, R. E. (2003). Personality, culture, and subjective well-being: Emotional and cognitive evaluations of life. Annual Review of Psychology, 54(1), 403-425. doi: 10.1146/annurev.psych.54.101601.145056

Durlak, J. A., Weissberg, R. P., Dymnicki, A. B., Taylor, R. D., \& Schellinger, K. B. (2011). The impact of enhancing students' social and emotional learning: A meta-analysis of school-based universal interventions. Child Development, 82(1), 405-432. doi: 10.1111/j.1467-8624.2010.01564.x

Elbertson, N., Brackett, M., \& Weissberg, R. (2010). School-based social and emotional learning (SEL) programming: Current perspectives. In A. Hargreaves, A. Lieberman, M. Fullan, \& D. Hopkins (Eds.), Second international handbook of educational change (pp. 1017-1028). London: Springer.

Fernández-Abascal, E. G., \& Martín-Díaz, M. D. (2019). Relations between dimensions of emotional intelligence, specific aspects of empathy, and non-verbal sensitivity. Frontiers in Psychology, 10, 1066. doi: $10.3389 /$ fpsyg.2019.01066

Fornell, C., \& Larcker, D. F. (1981). Evaluating structural equation models with unobservable variables and measurement error. Journal of Marketing Research, 18(1), 39-50. doi: 10.2307/3151312

Frydenberg, E. (2010). Think positively! A course for developing coping skills in adolescents. Hampshire: Continuum International Publishing Group.

Garrard, W. M., \& Lipsey, M. W. (2007). Conflict resolution education and antisocial behavior in U.S. schools: A meta-analysis. Conflict Resolution Quarterly, 25(1), 9-38. doi: 10.1002/crq.188

Gartland, D., Bond, L., Olsson, C. A., Buzwell, S., \& Sawyer, S. M. (2011). Development of a multi-dimensional measure of resilience in adolescents: the Adolescent Resilience Questionnaire. BMC Medical Research Methodology, 11, 134. doi: 10.1186/1471-2288-11-134

Gilbert, K. E. (2012). The neglected role of positive emotion in adolescent psychopathology. Clinical Psychology Review, 32(6), 467-481. doi: 10.1016/j.cpr.2012.05.005

Gillies, R. M. (2003). Structuring co-operative learning experiences in primary school. In R. M. Gillies \& A. F. Ashman (Eds.), Co-operative Learning-The social and intellectual outcomes of learning in groups (pp. 36-53). London: Routledge.

Gravesteijn, C., Diekstra, R., Sklad, M., \& de Winter, M. (2011). The effects of a Dutch school-based social and emotional learning programme (sel) on suicidality in adolescents. International Journal of Mental Health Promotion, 13(4), 4-16. doi: 10.1080/14623730.2011.9715664

Guasp Coll, M., Navarro-Mateu, D., Giménez-Espert, M. D. C., \& Prado-Gascó, V. J. (2020). Emotional intelligence, empathy, self-esteem, and life satisfaction in spanish adolescents: Regression vs. QCA models. Frontiers in Psychology, 11, 1629. doi: 10.3389/fpsyg.2020.01629

Haddadi, P., \& Besharat, M. A. (2010). Resilience, vulnerability and mental health. Procedia - Social and Behavioral Sciences, 5, 639-642. doi: 10.1016/j.sbspro.2010.07.157

Hromek, R., \& Roffey, S. (2009). Promoting social and emotional learning with games. Simulation \& Gaming, 40(5), 626-644. doi: 10.1177/1046878109333793

Hwang, E., \& Shin, S. (2018). Characteristics of nursing students with high levels of academic resilience: A cross-sectional study. Nurse Education Today, 71, 54-59. doi: 10.1016/j.nedt.2018.09.011 
Izard, C., Fine, S., Schultz, D., Mostow, A., Ackerman, B., \& Youngstrom, E. (2001). Emotion knowledge as a predictor of social behavior and academic competence in children at risk. Psychological Science, 12(1), 18-23. doi: 10.1111/1467-9280.00304

Jones, S. M., \& Bouffard, S. M. (2012). Social and emotional learning in schools: From programs to strategies and commentaries. Social Policy Report, 26(4), 1-33. doi: 10.1002/j.2379-3988.2012.tb00073.x

Kapıkıran, Ş. (2012). Validity and reliability of the Academic Resilience Scale in Turkish high school. Education, 132, 474-483. Retrieved from http://web.a.ebscohost.com/ehost/pdfviewer/pdfviewer?vid=2\&sid=4fd2a499-7f26-47e9-bbb1a631a5479f46\%40sdc-v-sessmgr03

Kim, B., \& Jeong, J. (2017). Dynamics of adolescents' life satisfaction and effect of class rank percentile: Evidence from Korean panel data. Journal of Economic Psychology, 59, 8-28. doi: 10.1016/j.joep.2017.01.002

Klohnen, E. C. (1996). Conceptual analysis and measurement of the construct of ego-resiliency. Journal of Personality and Social Psychology, 70(5), 1067-1079. doi: 10.1037/0022-3514.70.5.1067

Köker, S. (1991). Normal ve sorunlu ergenlerin yaşam doyumu düzeyinin karşılaştırılması (Unpublished master thesis). Ankara University, Ankara.

Kwok, S. Y. C. L., Gu, M., \& Kit, K. T. K. (2016). Positive psychology intervention to alleviate child depression and increase life satisfaction. Research on Social Work Practice, 26(4), 350-361. doi: $10.1177 / 1049731516629799$

Liu, Y., Wang, Z., \& Lü, W. (2013). Resilience and affect balance as mediators between trait emotional intelligence and life satisfaction. Personality and Individual Differences, 54(7), 850-855. doi: 10.1016/j.paid.2012.12.010

Liu, Y., Wang, Z.-H., \& Li, Z.-G. (2012). Affective mediators of the influence of neuroticism and resilience on life satisfaction. Personality and Individual Differences, 52(7), 833-838. doi: 10.1016/j.paid.2012.01.017

Lucas, R. E., Diener, E., \& Suh, E. (1996). Discriminant validity of well-being measures. Journal of Personality and Social Psychology, 71(3), 616-628. doi: 10.1037/0022-3514.71.3.616

MacKinnon, D. P., Fairchild, A. J., \& Fritz, M. S. (2007). Mediation Analysis. Annual Review of Psychology, 58(1), 593-614. doi: 10.1146/annurev.psych.58.110405.085542

Marilaf Caro, M., San-Martín, M., Delgado-Bolton, R., \& Vivanco, L. (2017). Empathy, loneliness, burnout, and life satisfaction in Chilean nurses of palliative care and homecare services. Enfermería Clínica (English Edition), 27(6), 379-386. doi: 10.1016/j.enfcle.2017.04.010

Martin, A. J., \& Marsh, H. W. (2006). Academic resilience and its psychological and educational correlates: A construct validity approach. Psychology in the Schools, 43(3), 267-281. doi: 10.1002/pits.20149

Mestre, J. M., Guil, R., Lopes, P. N., Salovey, P., \& Gil-Olarte, P. (2006). Emotional intelligence and social and academic adaptation to school. Psicothema, 18, 112-117. Retrieved from http://www.psicothema.com/pdf/3285.pdf

Midford, R., Cahill, H., Lester, L., Ramsden, R., Foxcroft, D., \& Venning, L. (2018). Alcohol prevention for school students: Results from a 1-year follow up of a cluster-randomised controlled trial of harm minimisation school drug education. Drugs: Education, Prevention and Policy, 25(1), 88-96. doi: 10.1080/09687637.2017.1290788

Midford, R., Ramsden, R., Lester, L., Cahill, H., Mitchell, J., Foxcroft, D. R., \& Venning, L. (2014). Alcohol Prevention and School Students: Findings from an Australian 2-year trial of integrated harm minimization school drug education. Journal of Drug Education, 44(3-4), 71-94. doi: $10.1177 / 0047237915579886$ 
Mwangi, C.N., Okatcha, F.M., Kinai, T.K., Ireri, A.M. (2015). Relationship between academic resilience and academic achievement among secondary school students in Kiambu County, Kenya. International Journal of School and Cognitive Psychology, 01(s2), 003. doi: 10.4172/2469-9837.S2-003

Ng, Z. J., E. Huebner, S., \& J. Hills, K. (2015). Life satisfaction and academic performance in early adolescents: Evidence for reciprocal association. Journal of School Psychology, 53(6), 479-491. doi: 10.1016/j.jsp.2015.09.004

Proctor, C. L., Linley, P. A., \& Maltby, J. (2009). Youth life satisfaction: A review of the literature. Journal of Happiness Studies, 10(5), 583-630. doi: 10.1007/s10902-008-9110-9

Ran, H., Cai, L., He, X., Jiang, L., Wang, T., Yang, R., ... Xiao, Y. (2020). Resilience mediates the association between school bullying victimization and self-harm in Chinese adolescents. Journal of Affective Disorders, 277, 115-120. doi: 10.1016/j.jad.2020.07.136

Salovey, P., \& Mayer, J. D. (1990). Emotional intelligence. Imagination, Cognition and Personality, 9(3), 185-211. doi: 10.2190/dugg-p24e-52wk-6cdg

Salovey, P., Mayer, J., Caruso, D., \& Yoo, S. (2008). The Positive psychology of emotional intelligence. Counterpoints, 336, 185-208. Retrieved from http://www.jstor.org/stable/42980149

Savci, M., Akat, M., Ercengiz, M., Griffiths, M. D., \& Aysan, F. (2020). Problematic social media use and social connectedness in adolescence: The mediating and moderating role of family life satisfaction. International Journal of Mental Health and Addiction. doi: 10.1007/s11469-020-00410-0

Secer, I., \& Ulas, S. (2020). The mediator role of academic resilience in the relationship of anxiety sensitivity, social and adaptive functioning, and school refusal with school attachment in high school students. Frontiers in Psychology, 11, 557. doi: 10.3389/fpsyg.2020.00557

Seligman, M. E. P., Steen, T. A., Park, N., \& Peterson, C. (2005). Positive psychology progress: Empirical validation of interventions. American Psychologist, 60(5), 410-421. doi: 10.1037/0003-066x.60.5.410

Smith, J. M. T. M. (2012). Effects of a socialemotional learning program on the resiliency of students at risk (Doctoral dissertation). Retrieved from ProQuest Dissertations and Theses database. (UMI No. 3512466).

Steel, P., Schmidt, J., \& Shultz, J. (2008). Refining the relationship between personality and subjective wellbeing. Psychological Bulletin, 134(1), 138-161. doi: 10.1037/0033-2909.134.1.138

Stockings, E. A., Degenhardt, L., Dobbins, T., Lee, Y. Y., Erskine, H. E., Whiteford, H. A., \& Patton, G. (2015). Preventing depression and anxiety in young people: A review of the joint efficacy of universal, selective and indicated prevention. Psychological Medicine, 46(1), 11-26. doi: 10.1017/s0033291715001725

Tabachnick, B. G., \& Fidell, L. S., (2013). Using multivariate statistics. Boston: Pearson.

Tamannaeifar, M., \& Shahmirzaei, S. (2019). Prediction of academic resilience based on coping styles and personality traits. Practice in Clinical Psychology, 1-10. doi: 10.32598/jpcp.7.1.1

Totan, T. (2018). Öz-farkındalık, sosyal farkındalık, öz-yönetim, ilişki kurma becerileri ve sorumlu karar verme temelinde Sosyal ve Duygusal Öğrenme Ölçeği'nin geliştirilmesi. Marmara Üniversitesi Atatürk Ĕ̆itim Fakültesi Eğitim Bilimleri Dergisi, 48(48), 41-58. doi: 10.15285/maruaebd.393209

Tugade, M. M., \& Fredrickson, B. L. (2004). Resilient individuals use positive emotions to bounce back from negative emotional experiences. Journal of Personality and Social Psychology, 86(2), 320-333. doi: 10.1037/0022-3514.86.2.320

Turan, M. E., \& İskender, M. (2020). Ergenlerde kariyer ve yetenek gelişimi öz-yeterliğinin, üst bilişsel farkındalık, yaşam doyumu ve algılanan arkadaş sosyal desteği ile ilişkisi. Ekev Akademi Dergisi, 84, 435-448. doi: 10.17753/ekev1373

Van Hoek, G., Portzky, M., \& Franck, E. (2019). The influence of socio-demographic factors, resilience and stress reducing activities on academic outcomes of undergraduate nursing students: A cross-sectional research study. Nurse Education Today, 72, 90-96. doi: 10.1016/j.nedt.2018.10.013 
Wang, H., Chu, J., Loyalka, P., Xin, T., Shi, Y., Qu, Q., \& Yang, C. (2016). Can social-emotional learning reduce school dropout in developing countries? Journal of Policy Analysis and Management, 35(4), 818-847. doi: 10.1002/pam.21915

Weissberg, R. P., Durlak, J. A., Domitrovich, C. E., \& Gullotta, T. P. (2015). Social and emotional learning: Past, present and future. In J. A. Durlak, C. P. Domitrovich, R. E. Weissberg, \& T. P. Gullotta (Eds.), Handbook of social and emotional learning: Research and practice (pp. 348-360). New York: Guilford Press.

Wills, G., \& Hofmeyr, H. (2019). Academic resilience in challenging contexts: Evidence from township and rural primary schools in South Africa. International Journal of Educational Research, 98, 192-205. doi: 10.1016/j.ijer.2019.08.001

Wilson, S. J., \& Lipsey, M. W. (2007). School-based interventions for aggressive and disruptive behavior. American Journal of Preventive Medicine, 33(2), 120-143. doi: 10.1016/j.amepre.2007.04.011

Woodard, K., \& Pollak, S. D. (2020). Is there evidence for sensitive periods in emotional development? Current Opinion in Behavioral Sciences, 36, 1-6. doi: 10.1016/j.cobeha.2020.05.004

World Health Organization. (2006). Orientation programme on adolescent health for health-care providers. Retrieved from https://apps.who.int/iris/bitstream/handle/10665/42868/9241591269_ Handout_eng.pdf;jsessionid=C1811676C3FDE55996002FF24DB026E7? sequence $=2$

Zandi, M. (2012). The role of emotional intelligence in french language learning and academic success of the male students. Procedia - Social and Behavioral Sciences, 46, 5714-5717. doi: 10.1016/j.sbspro.2012.06.503

Zeman, J., Cassano, M., Perry-Parrish, C., \& Stegall, S. (2006). Emotion regulation in children and adolescents. Journal of Developmental \& Behavioral Pediatrics, 27(2), 155-168. doi: 10.1097/00004703-200604000-00014 